\title{
Od Hermanna Hoogewega do Hermanna Golluba: Z dziejów Archiwum Państwowego w Szczecinie (Staatsarchiv Stettin). Recenzja monografii Macieja Szukały, Archiwum Państwowe w Szczecinie w latach 1914-1945. Ludzie i działalność, Archiwum Państwowe w Szczecinie, Naczelna Dyrekcja Archiwów Państwowych w Warszawie, Szczecin-Warszawa 2019, ss. 269
}

\author{
Krystian Maciej Szudarek \\ Uniwerstyet Szczeciński / University of Szczecin (Poland) \\ krystian.szudarek@usz.edu.pl, ORCID 0000-0001-9908-1055
}

\section{STRESZCZENIE}

Recenzowana monografia omawia dzieje Archiwum Państwowego w Szczecinie (Staatsarchiv Stettin) w okresie od wybuchu pierwszej wojny światowej do zakończenia drugiej wojny światowej. W tych latach dyrektorami archiwum byli kolejno: Hermann Hoogeweg (1913-1923), Otto Grotefend (1923-1930), Erich Randt (1930-1935) i Adolf Diestelkamp (1935-1945). W okresie II wojny światowej, w związku ze służbą wojskową Adolfa Diestelkampa, funkcje kierownika archiwum pełnili Fritz Morré (1939-1941) i Hermann Gollub (1941-1945). Działalność archiwum została ukazana w monografii przez pryzmat funkcji, jakie pełnią instytucje tego typu (gromadzenie, przechowywanie, opracowywanie i udostępnianie zasobu), na tle przemian politycznych i społecznych zachodzących w Niemczech. Dużo miejsca autor poświęcił pracownikom merytorycznym archiwum i prowadzonym przez nich badaniom naukowym. W tym kontekście ukazał kształtowanie się nowego typu archiwisty zaangażowanego politycznie, włączającego się w niemieckie badania wschodnie (deutsche Ostforschung).

\author{
SŁOWA KLUCZOWE \\ Archiwum \\ Państwowe \\ w Szczecinie \\ (Staatsarchiv \\ Stettin), niemiecka \\ państwowa służba \\ archiwalna, Hermann \\ Hoogeweg, \\ Otto Grotefend, \\ Erich Randt, \\ Adolf Diestelkamp, \\ Fritz Morré, \\ Hermann Gollub, \\ niemieckie badania \\ wschodnie (deutsche \\ Ostforschung), \\ antysemityzm \\ w III Rzeszy
}

From Hermann Hoogeweg to Hermann Gollub: history of the State Archives in Szczecin (Staatsarchiv Stettin). Review of the monograph by Maciej Szukała, Archiwum Państwowe w Szczecinie w latach 1914-1945. Ludzie i działalność, Archiwum Państwowe w Szczecinie, Naczelna Dyrekcja Archiwów Państwowych w Warszawie, Szczecin-Warsaw 2019, pp. 269

\section{SUMMARY}

The reviewed monograph gives a description of the history of the State Archives in Szczecin (Staatsarchiv Stettin) from the beginning of the First World War to the end of the Second Word War. Within that period the Archive had following directors: Hermann Hoogeweg (1913-1923),
KEYWORDS

State Archives

in Szczecin

(Staatsarchiv

Stettin), German 
Otto Grotefend (1923-1930), Erich Randt (1930-1935) and Adolf Diestelkamp (1935-1945). During the Second World War Fritz Morré (1939-1941) and then Hermann Gollub (1941-1945) deputized for Adolf Diestelkamp when he did military service. The monograph take a look at how the Archives performed its typical functions (collecting, preserving, processing and providing access to archival materials) in the context of the political and social transformation in Germany. The author puts a lot of emphasis on professional working in the Archives and their academic research to show the emergence of a new type of politically engaged archivist who joined the studies on Eastern Europe (deutsche Ostforschung). state archive service, Hermann Hoogeweg, Otto Grotefend, Erich Randt, Adolf Diestelkamp, Fritz Morré, Hermann Gollub, German research on Eastern Europe (deutsche Ostforschung), antisemitism in the Third Reich

W 2019 r. nakładem Archiwum Państwowego w Szczecinie oraz Naczelnej Dyrekcji Archiwów Państwowych w Warszawie ukazała się książka pt. Archiwum Państwowe w Szczecinie w latach 1914-1945. Ludzie i działalność. Stanowi ona długo oczekiwaną kontynuację wydanej przed półwieczem monografii Lucyny Turek-Kwiatkowskiej, która omówiła dzieje tej placówki do wybuchu I wojny światowej ${ }^{1}$. Jej autorem jest dr hab. Maciej Szukała, pracownik Archiwum Państwowego w Szczecinie, który w swoich badaniach naukowych podejmuje tematy związane z historią społeczną i historią kultury na Pomorzu i w Niemczech, zajmując się głównie ruchem stowarzyszeniowym i życiem naukowo-kulturalnym pruskiej prowincji Pomorze ${ }^{2}$, administracją i prasą pomorską oraz filmem okresu III Rzeszy. Jako archiwista publikuje także prace z zakresu aktoznawstwa i archiwoznawstwa. W dorobku naukowym Maciej Szukały na szczególną uwage zasługują prace bezpośrednio dotyczące problematyki recenzowanej rozprawy poświęcone zaangażowaniu pruskich archiwów w niemieckie badania wschodnie (deutsche Ostforschung) ${ }^{3}$ oraz różnym aspektom funkcjonowania Archiwum Pań-

1 L. Turek-Kwiatowska, $Z$ dziejów służby archiwalnej. Archiwa na Pomorzu Zachodnim w latach 1808-1914, Warszawa 1968.

2 Zob. m. in.: M. Szukała, Powstanie i działalność Towarzystwa Historii i Starożytności Pomorza w Szczecinie w latach 1824-1918. Z dziejów pomorskiej nauki i kultury XIX i początku XX wieku, Szczecin 2000.

3 Zob.m.in.:idem, Pruskiearchiwapaństwowe aniemieckiebadaniawschodnie (deutsche Ostforschung) w okresie międzywojennym XX wieku (1918-1939). Między nauka a politycznym zaangażowaniem, Szczecin-Warszawa 2011; idem, Polityczne aspekty badań wschodnich na przykładzie działalności Fritza Morrégo z Archiwum Państwowego w Szczecinie, „Szczecińskie Studia Historyczne” 2000, $\mathrm{nr}$ 13, s. 55-67; idem, Archiwiści niemieccy wobec badań wschodnich w okresie międzywojennym (ze szczególnym uwzględnieniem ośrodka szczecińskiego), „Stargardia” 2002, t. 2, s. 255-271; idem, Stettiner Archivare und die „deutsche Ostforschung”. Die Korrepondenz zwischen Albert Brackmann und Adolf Diestelkamp in den Jahren 1935 bis 1941, „Berichte und Forschungen. Jahrbuch des 
stwowego w Szczecinie 4 . Podjęty temat wpisuje się więc w jego zainteresowania naukowe. Jest to o tyle istotne, że Maciej Szukała co prawda skupia się na dziejach instytucji, ale czyni to z perspektywy związanych z nią ludzi - archiwistów i historyków, których losy osadza w kontekście przemian politycznych i społecznych w Niemczech. Nie pomija także odniesień do sytuacji w Szczecinie. Monografia wypełnia więc lukę badawczą dotyczącą dziejów archiwum szczecińskiego ${ }^{5}$, a panoramiczne podejście do zagadnienia powoduje, że książka wnosi ważki przyczynek do dziejów miasta i regionu. Stanowi także studium przypadku ukazującego politykę wprzęgania badań naukowych w Niemczech po 1933 r. w system państwa narodowosocjalistycznego.

Monografia składa się ze wstępu, czterech rozdziałów, uwag końcowych, zestawienia źródeł i literatury, spisu tabel oraz dodatku (patrz niżej), streszczeń w językach niemieckim i angielskim, a także fotografii pracowników szczecińskiego archiwum. Selektywne korzystanie z monografii ułatwia dobrze opracowany indeks osobowy i rzeczowy. Rozdziały zostały wyodrębnione na podstawie kryterium chronologiczno-rzeczowego i omawiają dzieje archiwum w kolejnych okresach historycznych (I wojna światowa, Republika Weimarska oraz lata III Rzeszy podzielo-

Bundesinstituts für Kultur und Geschichte der Deutschen im östlichen Europa" 2002, Bd. 10, s. 27-58.

4 Zob.: idem, Archiwista Roland Seeberg Elverfeldt (1909-1993) w świetle źródeł przechowywanych w Archiwum Państwowym w Szczecinie, „Szczeciński Informator Archiwalny” 2003, $\mathrm{nr}$ 17, s. 121-129; idem, Udostępnianie akt polskim naukowcom przez pruskie władze archiwalne w schyłkowym okresie Republiki Weimarskiej i w III Rzeszy, [w:] Świat Słowian w języku i kulturze, 5. Kulturologia, red. E. Komorowska, D. Dziadosz, Szczecin 2004, s. 110-119; idem, Szczeciński epizod w działalności archiwalnej Gerharda Zimmermanna. Przyczynek do dziejów Archiwum Państwowego w Szczecinie w okresie II wojny światowej, „Stargardia” 2006, t. 4, s. 243-250; idem, Antysemityzm w służbie archiwalnej III Rzeszy na przykładzie Archiwum Państwowego w Szczecinie. „Aryjskość” jako warunek dostępu do zasobów archiwalnych w świetle przepisów i praktyki w pruskiej prowincji Pomorze w latach 1933-1945, [w:] Żydzi oraz ich sq̨siedzi na Pomorzu Zachodnim w XIX i XX wieku, red. M. Jarosiewicz, W. Stępiński, Warszawa 2007, s. 295-304; idem, Archiwista Rolf Reuter (1909-1945) w świetle materiatów archiwalnych przechowywanych $w$ Archiwum Państwowym w Szczecinie, „Szczeciński Informator Archiwalny" 2007, nr 20, s. 101-111; idem, Zasady udostępniania materiałów archiwalnych w Archiwum Państwowym w Szczecinie w okresie międzywojennym, „Archeion” 2017, t. 118 , s. 87-98.

5 Dotychczas dysponowaliśmy jedynie trzema artykułami naukowymi na ten temat. Zob.: M. Stelmach, Zarys działalności Archiwum Państwowego w Szczecinie w latach 1918-1939, „Szczeciński Informator Archiwalny” 1993, nr 8, s. 13-28; idem, Losy archiwaliów szczecińskich w okresie II wojny światowej, „Szczeciński Informator Archiwalny” 1995, nr 9, s. 17-39; D. Schleinert, Das Staatsarchiv Stettin von 1939 bis 1945, „Baltische Studien” Neue Folge, 2013, Bd. 99, s. 111-131. 
ne na okres do i po wybuchu II wojny światowej). Ich struktura jest schematyczna, opiera się na 6-8 podrozdziałach. Przestawiają one kolejno uwarunkowania ogólne działalności archiwum i skład personalny placówki oraz opis pracy archiwum w ramach funkcji, jakie spełniają instytucje tego typu, czyli gromadzenie, opracowanie i udostępnianie. W każdym rozdziale umieszczono podrozdział poświęcony działalności naukowej pracowników oraz postępom prac nad inwentaryzacją archiwów niepaństwowych. Rozdział trzeci uzupełniony jest jeszcze uwagami na temat kwestii antysemityzmu w służbie archiwalnej oraz niemieckich badań wschodnich, zaś czwarty zawiera omówienie zagadnienia ewakuacji zasobu archiwum szczecińskiego pod koniec II wojny światowej.

Wstęp (s. 5-20) M. Szukała rozpoczyna od rozważań ogólnych na temat tożsamości archiwum instytucji. Poszukując odpowiedzi na pytanie: „czym archiwa są w istocie i jaką rolę pełnią w społeczeństwie” (s. 7), dostrzega, że z jednej strony to instytucje będące elementem aparatu administracyjnego państwa, funkcjonujące w określonym porządku prawnym, z drugiej zaś placówki naukowe, które powinny utrzymywać niezależność badań. Dostrzega potrzebę osadzenia dziejów każdej placówki w szerokim kontekście nie tylko ustrojowym, ale także politycznym. Akcentując takie podejście, zapowiada swoją perspektywę narracji na temat archiwum szczecińskiego. $Z$ tego samego względu wstęp jest także miejscem, w którym autor szkicuje genezę nowoczesnego archiwum jako instytucji, a także okoliczności w jakich kształtowała się pruska sieć archiwalna i - w konsekwencji w 1831 r. - powstało prowincjonalne archiwum w Szczecinie. Wskazuje również na węzłowe zagadnienia związane z dziejami tej instytucji do wybuchu I wojny światowej, w końcowej części charakteryzuje źródła i literaturę przedmiotu.

Rozdział I, zatytułowany „Archiwum Państwowe w Szczecinie w okresie I wojny światowej" (s. 21-54) rozpoczyna się uwagami ogólnymi na temat trudnej sytuacji placówki w latach wojny. Autor przywołuje biografie ówczesnych pracowników merytorycznych archiwum, tj. znaczących dla nauki historycznej i archiwistyki postaci takich jak: dr Hermann Hoogeweg - od 1913 r. dyrektor archiwum, dr Karl Otto Grotefend, dr Hermann von Peteresdorff oraz dr Heinrich Otto Meisner. Przechodząc do omówienia zagadnień związanych z gromadzeniem i przechowywaniem zasobu, M. Szukała przedstawia nabytki z lat wojny, informując przy okazji o jednostkach miar, jakimi posługiwali się archiwiści niemieccy. Odnosi się również do spraw biblioteki archiwalnej.

W części poświęconej opracowywaniu zasobu autor zwraca uwagę na zmiany, jakie zachodziły na przełomie XIX i XX w. w zakresie obowiązujących w tej 
materii przepisów, a które związane były z rozwojem myśli archiwalnej w Prusach i w Niemczech, w tym przyjęciem zasady proweniencji (Provenienzprinzip), nazywanej również zasadą przynależności zespołowej. M. Szukała błędnie jednak nazywa ją „zasadą proweniencji zespołowej” (s. 36, 37). Zasada proweniencji została wprowadzona wytycznymi z 1 lipca 1881 r. dotyczącymi opracowania zasobu w Geheimes Staatsarchiv w Berlinie. Autor odsyła zainteresowanego tym zagadnieniem czytelnika do monografii Johanny Weiser, w której opublikowano w aneksie treść tych wytycznych ${ }^{6}$. Według tej autorki zostały one przekazane archiwom prowincjonalnym do wiadomości i stosowania zarządzeniem z 12 października $1896^{7}$. M. Szukała twierdzi natomiast, że miało to miejsce dopiero w 1897 r., na podstawie zarządzenia ówczesnego Generalnego Dyrektora Geheimes Staatsarchiv w Berlinie prof. Rheinholda Kosera, nie podaje jednak w przypisie odniesienia do źródła. M. Szukała podkreślił jednocześnie, że zasady zawarte w wytycznych z 1881 r. wprowadzano stopniowo (s. 37). Warto w tym kontekście przypomnieć opinię prof. Mieczysława Stelmacha, który autorytatywnie stwierdził, że zasadę proweniencji zaczęto stosować powszechnie w Staatsarchiv w Szczecinie dopiero w okresie międzywojennym ${ }^{8}$.

W ramach wprowadzenia M. Szukała kreśli również zakres prac związanych z opracowaniem zasobu przeprowadzonych do wybuchu wojny, zwracając uwagę na ograniczone działania na tym polu w latach 1914-1918. Wartościową część retrospekcyjną posiada także podrozdział dotyczący udostępniania, w którym autor przedstawia zasady i regulacje prawne jakie obowiązywały w tym zakresie od początku istnienia archiwum szczecińskiego. Od 1910 r. udostępniano akta wytworzone do 1806 r., od 1911 r. także studentom. W latach wojny ilość kwerend spadła znacząco.

Podobne, szersze wprowadzenie towarzyszy omawianiu działalności naukowej kadry merytorycznej archiwum. Istotną rolę w procesie ewolucji celów i funkcji archiwów historycznych odegrała instrukcja dla urzędników archiwów z 31 sierpnia 1867 sygnowana przez premiera Prus Otto von Bismarcka, która regulowała kompetencje archiwów prowincjonalnych i sposób ich funkcjonowania oraz okre-

$6 \quad$ Zob.: J. Weiser, Geschichte der preußischen Archivvervaltung und ihrer Leiter. Von den Anfängen unter Staatskanzler von Hardenberg bis zur Ausflösung im Jahre 1945, Kolonia-Weimar-Wiedeń 2000, s. 247-251, Anhang 7, „Regulativ für die Ordnungsarbeiten im Geheimen Staatsarchiv. Berlin, 1881, Juli 1".

7 Ibidem, s. s. 247, przypis 1.

$8 \quad$ M. Stelmach, Zarys działalności..., s. 21. 
ślała obowiązki i prawa archiwistów w nich zatrudnionych do celów naukowych ${ }^{9}$. M. Szukała szczegółowo omówił ten dokument, lecz dwukrotnie błędnie określił powyższą instrukcję mianem „ustawy archiwalnej z 1867 r.” (s. 43, 44).

M. Szukała zwraca w tym kontekście uwagę na znaczenie Heinricha von Sybla, Generalnego Dyrektora Pruskich Archiwów Państwowych, i utworzenie Szkoły Archiwalnej w Marburgu ${ }^{10}$. Podkreśla jednak, że archiwiści szczecińscy byli przede wszystkim historykami regionu publikującymi w periodykach Towarzystwa Historii i Starożytności Pomorza (mającego swoją siedzibę w szczecińskim archiwum), czyli „Baltische Studien” ${ }^{11}$ i „Monatsblätter” ${ }^{12}$. Końcową część pierwszego rozdziału autor poświęcił zagadnieniu inwentaryzacji archiwów niepaństwowych, czyli komunalnych, kościelnych, stowarzyszeń i rodowych, wskazując, że to zadanie państwowa służba archiwalna realizowała od II połowy XIX w. W latach wojny pracownicy archiwum szczecińskiego nie podejmowali takich prac, wznawiając je dopiero w latach dwudziestych XX w.

„Działalność archiwum w czasach Republiki Weimarskiej” to tytuł drugiego rozdziału monografii (s. 55-93). Zgodnie z przyjętym schematem konstrukcji, tę część pracy autor rozpoczyna od nakreślenia sytuacji ogólnej w Niemczech i Szczecinie po zakończeniu wojny, by następnie skupić się na trudnościach, z jakimi musiał borykać się dyrektor szczecińskiego archiwum. Omawia prace modernizacyjne obiektu. Wskazuje również, że dopiero w 1922 r. usunięto z archiwum wszelkie symbole wskazujące na monarchiczną przeszłość państwa. W kolejnej części rozdziału („Stan personalny”, s. 60-77) M. Szukała przedstawia biografie nowych pracowników zatrudnionych w archiwum. Interesująco omawia okolicz-

9 Zob.: J. Weiser, Geschichte der preußischen Archivvervaltung..., s. 48-49, 230-235, Anhang 5, „Instruktion für die Beamten der Staats-Archive in den Provinzen. Berlin, 1867, August 31”.

10 Zob. także: W. Blöß, Anfänge archivarischer Berufsausbildung in Deutschland. Die „Archivschule” in Marburg 1894, „Archivmitteilungen” 1959, Jg. 9, H. 2, s. 52-59.

11 „Baltische Studien”, najstarsze pomorskie naukowe czasopismo historyczne, ukazywało się w latach 1832-1940 w dwóch seriach: starszej (Alte Folge, do 1896 r.) i nowej (Neue Folge, od 1897 r.). Po II wojnie światowej, w 1995 r., wznowione na terenie Niemiec Zachodnich. Ukazuje się do dnia dzisiejszego. Tomy „Baltische Studien” z lat 1832-2002 są dostępne online na stronie biblioteki cyfrowej Mecklenburg Vorpommern: https://www.digitale-bibliothek-mv.de/ viewer/toc/PPN559838239/1/LOG_0000/ [dostęp: 6.05.2021].

12 „Monatsblätter der Gesselschaft für Geschichte und Altertumskunde”, czasopismo ukazujące się w latach 1887-1942. Tomy „Monatsblätter der Gesselschaft für Geschichte und Altertumskunde" z lat 1887-1920 są dostępne online na stronie biblioteki cyfrowej Mecklenburg Vorpommern: https://www.digitale-bibliothek-mv.de/viewer/toc/PPN883720280/1/ [dostęp: 6.05.2021], natomiast tomy z lat 1897-1942 na stronie Repozytorium Cyfrowego Instytutów Naukowych: https://rcin.org.pl/publication/9329\#structure [dostęp: 6.05.2021]. 
ności, w jakich jego nowym dyrektorem został Erich Randt, reprezentujący typ zaangażowanego politycznie archiwisty, zgodny z programem nakreślonym przez nowego Generalnego Dyrektora Pruskich Archiwów Państwowych prof. Alberta Brackmanna $^{13}$. Archiwiści mieli być nie tylko znawcami historii regionalnej, ale przede wszystkim angażować się w ukazywanie rozwoju niemieckości na Wschodzie. Charakteryzując gromadzenie i opracowywanie zasobu, autor podkreśla, że dopiero pod koniec omawianego okresu można zauważyć wzrost nabytków, a następnie analizuje szczegółowo akta przekazane do archiwum szczecińskiego w latach 1919-1932 przez sądy, administrację państwową oraz spuścizny i depozyty władz samorządowych i kościelnych.

W zakresie opracowywania w omawianym okresie archiwiści szczecińscy zajęli się najstarszymi zespołami, co zostało skrupulatnie opisane. Równie precyzyjnie M. Szukała przedstawił nowe zasady udostępnienia zasobu obowiązujące w okresie Republiki Weimarskiej, zaznaczając, że odrębne przepisy obowiązywały cudzoziemców, a zwłaszcza Polaków. Charakteryzując dorobek naukowy archiwistów szczecińskich, zwraca uwagę, że był on publikowany w dużej części na łamach szczecińskich periodyków: „Baltische Studien” i „Monatsblätter”. Odnosząc się do prac inwentaryzacyjnych archiwów niepaństwowych, podkreśla, że zostały one podjęte w połowie lat 20. we współpracy z Komisją Historyczną Pomorza i były prowadzone do początku II wojny światowej, obejmując zasięgiem 1/3 wszystkich powiatów pomorskich.

Kolejny, trzeci rozdział monografii obejmuje dzieje archiwum szczecińskiego w okresie III Rzeszy (do wybuchu wojny w 1939 r.). Autor w pierwszym podrozdziale zwraca uwagę na mającą miejsce wówczas silną integrację archiwów z celami narodowosocjalistycznej dyktatury oraz nowe zadania tych placówek wynikające z ustaw norymberskich z 1935 r. Prowadzone tam badania genealogiczne, czy też inaczej badania rodowe, stały się narzędziem w polityce antysemickiej państwa. Towarzyszyły temu zmiany kadrowe w archiwum szczecińskim, które M. Szukała szczegółowo referuje, kreśląc sylwetki kolejnych nowych pracowników. Zwraca też uwagę na szereg spraw związanych z funkcjonowaniem placówki, w tym coraz bardziej odczuwalny brak miejsca na akta w magazynie. Kwestię tę uszczegóławia w kolejnym podrozdziale, charakteryzując bezprecedensowy wzrost nabytków archiwum, zwłaszcza od 1934 r. Nowe zadania archiwów wpłynęły także na wzrost liczby użytkowników, co także zosta-

13 Zob. także: H. Meinert, Albert Brackmann und das deutsche Archivwesen, „Archivalische Zeitschrift" 1954, Bd. 49, s. 127-138. 
ło szczegółowo omówione przez autora. W tej części pracy odniósł się on również ponownie do kwerend polskich naukowców w Szczecinie. Przy omawianiu badań naukowych poszczególnych pracowników podkreślił, że były koordynowane i stymulowane przez Generalnego Dyrektora, zaś poruszane zagadnienia nawiązywały do współczesnych problemów politycznych. Wartościową część pracy stanowi podrozdział dotyczący kwestii antysemityzmu w służbie archiwalnej (s. 137-144). Co prawda w niewielkim stopniu odnosi się ona do samego archiwum szczecińskiego, stwarza jednak istotny kontekst dla działalności tej placówki. W kolejnym podrozdziale autor omawia niemieckie badania wschodnie (deutsche Ostforschung) i problem kaszubszczyzny, gdyż w latach 30. widoczne było coraz większe zaangażowanie miejscowych archiwistów w „odpieranie polskich pretensji terytorialnych” (s. 146). Końcową część rozdziału M. Szukała poświęca omówieniu prób prawnego uregulowania powiązań między archiwami niepaństwowymi i państwową służbą archiwalną, a także kontynuowaniu prac inwentaryzacyjnych nad niepaństwowymi archiwami w powiatach, podając przy tym szereg informacji na temat instytucji opiekunów archiwalnych, o których wspomniał w poprzednim rozdziale.

Ostatni, czwarty rozdział, pt.: „Archiwum szczecińskie w okresie III Rzeszy (II wojna światowa 1939-1945, s. 157-209) M. Szukała rozpoczyna opisem trudnej sytuacji ogólnej w archiwach pruskich w latach wojny, a następnie przedstawia jak w omawianym czasie funkcjonowało archiwum szczecińske oraz jaka była jego sytuacja kadrowa. W okresie II wojny światowej, w związku ze służbą wojskową Adolfa Diestelkampa, funkcje kierownika archiwum pełnili Fritz Morré (1939-1941) i Hermann Gollub (1941-1945). W kolejnych częściach rozdziału autor omawia negatywny wpływ wojny na realizowanie podstawowych zadań archiwum w zakresie gromadzenia, opracowywania i udostępniania zasobu. Braki kadrowe nie sprzyjały także badaniom naukowym. W 1940 r. ukazał się ostatni tom „Baltische Studien”. Zawieszono także systematyczną inwentaryzację archiwów niepaństwowych. Szczególnie interesujący jest ponadto ostatni podrozdział poświęcony ewakuacji zasobu archiwum szczecińskiego (s. 195-206). W maju 1942 r. rozpoczęła się realizacja ustalonego jeszcze w 1938 r. ogólnego planu rozśrodkowania zasobów archiwów państwowych z poszczególnych miast na wypadek wojny. Działania te koordynował Komisarz do Ochrony Archiwaliów, którym został dr Ernst Zipfel. W Szczecinie odpowiadał za nie H. Gollub. Autor dokładnie relacjonuje kolejne etapy przewożenia akt i towarzyszące im decyzje. Do zakończenia 
wojny nie udało się ich w całości ewakuować. W grudniu 1944 r. z archiwum szczecińskiego wywieziono $80 \%$ zasobu. M. Szukała zaznacza, że H. Gollub opuścił Szczecin w kwietniu 1945 r., zaś po zakończeniu wojny organizował archiwum w Greifswaldzie.

Monografię zamykają uwagi końcowe (s. 207-209). Autor zwraca tu uwagę na znaczenie badanego okresu w dziejach archiwistyki oraz wpływ wydarzeń politycznych w Prusach (Niemczech) na funkcjonowanie archiwów, a w konsekwencji ukształtowanie się nowego, zaangażowanego wzoru archiwisty. W przypadku pracowników archiwum szczecińskiego oznaczało to włączanie się niektórych z nich w niemieckie badania wschodnie. M. Szukała podkreśla również wzrost nabytków archiwum szczecińskiego w badanym okresie i wynikające stąd trudności magazynowe, zaś w latach wojny zwraca uwagę na bezprecedensowe zadanie, z jakim musieli zmierzyć się archiwiści, czyli rozśrodkowanie zasobu, który tylko częściowo trafił z powrotem do archiwum szczecińskiego przejętego 1 sierpnia 1945 r. przez polską służbę archiwalną. Domknięciem tej problematyki jest część pracy zatytułowana „Dodatek” (s. 225-228). Jej treść stanowi przedruk spisu treści maszynopisu Bolesława Tuhana-Taurogińskiego (1904-1974) ${ }^{14}$, pierwszego dyrektora archiwum w polskim Szczecinie, będący spisem ewidencyjnym zespołów według numerów repozytur, który przygotował on na podstawie opracowania H. Hoogewega z 1913 r., a następnie uzupełnił ${ }^{15}$. Dokument ten daje obraz zasobu archiwum szczecińskiego przed 1945 r.

Podstawę źródłową recenzowanej monografii stanowią archiwalia zgromadzone przez autora podczas kwerend przeprowadzonych w Archiwum Państwowym w Szczecinie, Archiwum Państwowym we Wrocławiu oraz w trzech niemieckich archiwach - Bundesarchiv Dienstelle Berlin-Lichterfelde, Landesarchiv Greifswald i Geheimes Staatsarchiv Preussischer Kulturbesitz Berlin-Dahlem. W pracy wykorzystano również obszerną literaturę przedmiotu, zarówno tę starszą, jak i najnowszą. W zestawieniu bibliograficznym zabrakło jedynie artykułów opublikowanych w 2017 r. na łamach czasopisma „Archivar”, którego zeszyt czwarty z tego roku poświęcono tematowi „Archive und Nationalsozialismus”.

14 Zob.: M. Frankel, Bolesław Tuhan-Taurogiński. Pionierski organizator Szczecińskiego Archiwum Państwowego, „Kronika Szczecina” 2015/2016, nr 34, s. 189-192.

15 B. Tuhan-Taurogiński, Zespoły Archiwum Państwowego w Szczecinie, mps przechowywany w zbiorach Archiwum Państwowego w Szczecinie.

16 Zob. m.in.: S. Kriese, Konsistenz und Wandel der Preussischen „Archivarbeit” im Nationalsozialismus. Ein Arbeits- und Forschungsaufruf, „Archivar” 2017, Jg. 70, H. 4, s. 370-375; P.U. Weiß, Das Potsdamer Reichsarchiv in der Zeit des Nationalsozialismus. Ausgewählte Beobachtungen und 
Pewne zastrzeżenia i wątpliwości budzi przyjęta przez autora schematyczna struktura opracowania. Niektóre zadania archiwum, wyznaczające strukturę wewnętrzną publikacji, nie były w kolejnych okresach realizowane w takim samym stopniu, a niekiedy nawet w ogóle ich nie podejmowano, jak na przykład miało to miejsce w czasie I wojny światowej w odniesieniu do prac inwentaryzacyjnych archiwów niepaństwowych (s. 56). Wątpliwości co do zasadności chronologiczno-rzeczowej struktury monografii potwierdza włączenie do głównego nurtu narracji całych partii tekstu poświęconych wydarzeniom i procesom mającym miejsce przed 1914 r. Co prawda książka stanowi kontynuację badań na ten temat i naturalnym jest, że autor musi nawiązać do wcześniejszego okresu w dziejach archiwum szczecińskiego, jednak w niektórych podrozdziałach to właśnie retrospekcje stanowią zdecydowaną większość tekstu. Przyjęcie struktury odwrotnej, a więc rzeczowo-chronologicznej, z wprowadzeniem do poszczególnych zagadnień, pozwoliłoby również na wyraźniejsze wyeksponowanie pracowników merytorycznych związanych z archiwum oraz ukazanie archiwum w ujęciu bardziej dynamicznym. Sprzyjałoby to także całościowemu spojrzeniu na kwestie związane z gromadzeniem, opracowywaniem i udostępnianiem archiwaliów oraz innymi zakresami działalności szczecińskich archiwistów. Pozwoliłoby również na swobodne włączenie do rozprawy różnych kontekstów, czyli w tym przypadku kwestii antysemityzmu w służbie archiwalnej, która to - podobnie jak odniesienie do niemieckich badań wschodnich - bezsprzecznie stanowi bardzo wartościowy element recenzowanej rozprawy. Stwarzałoby także możliwość spojrzenia na dzieje archiwum z perspektywy kolejnych dyrektorów, których kadencje tworzyły przecież pewne zamknięte całości, co z kolei ułatwiłoby ocenę ich działalności i osiągnięć oraz udzielenie odpowiedzi na pytanie, czy (lub na ile) wywarli oni wpływ na pracę podległej im placówki jako badacze i archiwiści. Kwestia ta bowiem w pracy M. Szukały nie została omówiona w sposób wyczerpujący.

Przykładowo autor słusznie wskazał, że najważniejszym osiągnięciem organizacyjnym dyrektora E. Randta (1930-1935) „był podział zasobu na określone grupy zespołów lub poszczególne zespoły z nadaniem im numerów repozyturowych (Rep.)”. Szczegółową informację na ten temat, bez wskazania jednakże konkretnej daty wprowadzenia tego systemu, podał w rozdziale dotyczącym historii Archiwum Państwowego w Szczecinie w okresie Republiki Weimarskiej 
(s. 76-77), podczas gdy system repozytur został zaprowadzony w tym archiwum dopiero w 1933 r. ${ }^{17}$

Monografia M. Szukały jest jednak przede wszystkim publikacją, której bohaterem jest instytucja, i której działalność determinowały zadania i funkcje archiwów w Prusach (Niemczech) oraz sytuacja polityczna. Autor umiejętnie wskazuje, w jaki sposób nauka historyczna i archiwistyka stały się narzędziami systemu państwa narodowosocjalistycznego. W swojej narracji zachowuje równowagę między partiami tekstu, w których pietystycznie odtwarza przebieg wydarzeń i szczegółowo relacjonuje treści zawarte np. w urzędniczej korespondencji, a dodatkowymi informacjami przedstawiającymi rzeczywistość, w jakiej działała placówka i związani z nią ludzie. Praca M. Szukały jest więc rzetelną, godną polecenia publikacją zarówno dla adeptów archiwistyki, jak i wszystkich zainteresowanych dziejami Pomorza i Szczecina, która wraz z opracowaniem autorstwa L. Turek-Kwiatkowskiej oraz przewodnikiem po aktach niemieckich w zasobie miejscowego archiwum państwowego ${ }^{18}$ tworzy kompendium wiedzy o szczecińskim archiwum.

\section{Bibliografia}

Archiwum Państwowe w Szczecinie. Przewodnik po zasobie archiwalnym. Akta do 1945 roku, oprac. zbiorowe R. Gaziński, P. Gut, M. Szukała, Szczecin 2002.

Blöß W., Anfänge archivarischer Berufsausbildung in Deutschland. Die „Archivschule” in Marburg 1894, „Archivmitteilungen” 1959, Jg. 9, H. 2, s. 52-59.

Frankel M., Bolesław Tuhan-Taurogiński. Pionierski organizator Szczecińskiego Archiwum Państwowego, „Kronika Szczecina” 2015/2016, nr 34, s. 189-192.

Gut P., Procesy archiwotwórcze akt sądowych pruskiej prowincji Pomorze do 1945 roku, [w:] Archiwa instytucji wymiaru sprawiedliwości w służbie państwa i obywateli. Materiały III Krajowego Sympozjum Archiwalnego Łódź, 4-5 września 2001, red. J. Baranowski, U. Zarzycka-Sutter, Łódź 2001, s. 137-162.

Kriese S., Konsistenz und Wandel der Preussischen „Archivarbeit” im Nationalsozialismus. Ein Arbeitsund Forschungsaufruf, „Archivar” 2017, Jg. 70, H. 4, s. 370-375.

17 Zob.: M. Stelmach, Zarys działalności..., s. 21; P. Gut, Procesy archiwotwórcze akt sq̨dowych pruskiej prowincji Pomorze do 1945 roku, [w:] Archiwa instytucji wymiaru sprawiedliwości w stużbie państwa i obywateli. Materiały III Krajowego Sympozjum Archiwalnego Eódź, 4-5 września 2001, red. J. Baranowski, U. Zarzycka-Sutter, Łódź 2001, s. 155.

18 Archiwum Państwowe w Szczecinie. Przewodnik po zasobie archiwalnym. Akta do 1945 roku, oprac. zbiorowe R. Gaziński, P. Gut, M. Szukała, Szczecin 2002. 
Meinert H., Albert Brackmann und das deutsche Archivwesen, „Archivalische Zeitschrift” 1954, Bd. 49 , s. 127-138.

Schleinert D., Das Staatsarchiv Stettin von 1939 bis 1945, „Baltische Studien” Neue Folge, 2013, Bd. 99, s. 111-131.

Schmidt S., Der Weg der Archive im Zweiten Weltkrieg, „Archivar” 2017, Jg. 70, H. 4, s. 396-401.

Stelmach M., Losy archiwaliów szczecińskich w okresie II wojny światowej, „Szczeciński Informator Archiwalny" 1995, nr 9, s. 17-39.

Stelmach M., Zarys działalności Archiwum Państwowego w Szczecinie w latach 1918-1939, „Szczeciński Informator Archiwalny" 1993, nr 8, s. 13-28.

Szukała M., Antysemityzm w służbie archiwalnej III Rzeszy na przykładzie Archiwum Państwowego w Szczecinie. „Aryjskość” jako warunek dostępu do zasobów archiwalnych w świetle przepisów i praktyki w pruskiej prowincji Pomorze w latach 1933-1945, [w:] Żydzi oraz ich sąsiedzi na Pomorzu Zachodnim w XIX i XX wieku, red. M. Jarosiewicz, W. Stępiński, Warszawa 2007, s. 295-304.

Szukała M., Archiwista Roland Seeberg Elverfeldt (1909-1993) w świetle źródeł przechowywanych w Archiwum Państwowym w Szczecinie, „Szczeciński Informator Archiwalny” 2003, nr 17, s. 121-129.

Szukała M., Archiwista Rolf Reuter (1909-1945) w świetle materiałów archiwalnych przechowywanych w Archiwum Państwowym w Szczecinie, „Szczeciński Informator Archiwalny” 2007, nr 20, s. 101-111.

Szukała M., Archiwiści niemieccy wobec badań wschodnich w okresie międzywojennym (ze szczególnym uwzględnieniem ośrodka szczecińskiego), „Stargardia” 2002, t. 2, s. 255-271.

Szukała M., Polityczne aspekty badań wschodnich na przykładzie działalności Fritza Morrégo z Archiwum Państwowego w Szczecinie, „Szczecińskie Studia Historyczne” 2000, nr 13, s. 55-67.

Szukała M., Powstanie i działalność Towarzystwa Historii i Starożytności Pomorza w Szczecinie w latach 1824-1918. Z dziejów pomorskiej nauki i kultury XIX i poczq̨tku XX wieku, Szczecin 2000.

Szukała M., Pruskie archiwa państwowe a niemieckie badania wschodnie (deutsche Ostforschung) w okresie międzywojennym XX wieku (1918-1939). Między naukq a politycznym zaangażowaniem, Szczecin-Warszawa 2011.

Szukała M., Stettiner Archivare und die „deutsche Ostforschung”. Die Korrepondenz zwischen Albert Brackmann und Adolf Diestelkamp in den Jahren 1935 bis 1941, „Berichte und Forschungen. Jahrbuch des Bundesinstituts für Kultur und Geschichte der Deutschen im östlichen Europa" 2002, Bd. 10, s. 27-58.

Szukała M., Szczeciński epizod w działalności archiwalnej Gerharda Zimmermanna. Przyczynek do dziejów Archiwum Państwowego w Szczecinie w okresie II wojny światowej, „Stargardia” 2006, t. 4, s. $243-250$. 
Szukała M., Udostępnianie akt polskim naukowcom przez pruskie władze archiwalne w schyłkowym okresie Republiki Weimarskiej i w III Rzeszy, [w:] Świat Słowian w języku i kulturze, 5. Kulturologia, red. E. Komorowska, D. Dziadosz, Szczecin 2004, s. 110-119.

Szukała M., Zasady udostępniania materiałów archiwalnych w Archiwum Państwowym w Szczecinie w okresie międzywojennym, „Archeion” 2017, t. 118, s. 87-98.

Turek-Kwiatowska L., Z dziejów służby archiwalnej. Archiwa na Pomorzu Zachodnim w latach 18081914, Warszawa 1968.

Weiser J., Geschichte der preußischen Archivvervaltung und ihrer Leiter. Von den Anfängen unter Staatskanzler von Hardenberg bis zur Ausflösung im Jahre 1945, Kolonia-Weimar-Wiedeń 2000.

Weiß P.U., Das Potsdamer Reichsarchiv in der Zeit des Nationalsozialismus. Ausgewählte Beobachtungen und Befunde zur NS-Belastung, „Archivar” 2017, 70 Jg., H. 4, s. 376-384. 